DOI: https://doi.org/10.18524/2410-2601.2020.1(33).211974

УДК 130.2

олена Колесник

КОМІЧНЕ В ПЕРЕКЛАДІ «РУСЛАНА І ЛЮДМИЛИ»

\section{В. ФОКІНА}

В статті робиться огляд декількох поем XIX ст., в яких автори звертаються до літературних та фольклорно-етнографічних джерел, переробляючи їх в іронічному дусі. На прикладі переказу пушкінської поеми "Руслан і Людмила» В. Фокіна демонструється схожість та відмінність підходу до тієї само теми в оригіналі та переспіві.

Ключові слова: «Руслан $і$ Людмила», «Енеїда», комічне, переклад.

Постановка проблеми. 3 середини XVIII ст. в різних країнах Свропи почалося осмислення унікальності етнографічної та історичної спадшини кожного народу. Романтизм остаточно ствердив це нове усвідомлення, а фольклор - який став розглядатися в якості «концентрату» народного духу став об'єктом збору, публікації та вивчення. В Російській імперії кінця XVIII - початку ХІХ ст. відбулося декілька вдалих спроб створення авторського тексту з використанням фольклорного матеріалу. У відмінностях між цими талановитими творами можна побачити відбиток не лише індивідуальності творця, але й національного менталітету. В наш час, коли необхідно вибудовувати нові форми україно-російського культурного діалогу, має сенс дослідити паралельне створення в українській та російській культурі «програмних» героїко-комічних поем, а також спробу синтезу «традиції Котляревського» та «традиції Пушкіна» в перекладацькому проекті В. Фокіна.

Виклад основного матеріалу. Цікавість до фольклору була доволі масовою, а ініціатива щодо його популяризації далеко не завжди походила від професійних філологів. Так, Кірша Данилов, збирач та упорядник першої збірки російських народних билин та пісень (біля 1742), був «молотовим майстром» одного з уральських заводів. Зібраний «в полі» матеріал» піддавався різному ступеню обробки: від мінімального редагування вже наявних текстів - до створення авторських творів «в народному стилі»,далі, до використання лише окремих мотивів в радикально іншому, не фольклорному контексті. В таких переробках можуть виявлятися різні стратегії створення комічного ефекту: авторська іронія щодо першоджерела, відкрите пародіювання, змішування «високого» та «низького» в різних пропорціях тощо.

Одним з прикладів літературної обробки першоджерела з мінімальними змінами є «Горбоконик» П. Єршова. Фольклорна основа тут настільки сильна, що ані гумористичний тон, ані сполучення казкової фантастики з побутовими реаліями не приховують космологічну структуру, яка дозволяє використовувати текст як джерело з міфології.
Принципово інший варіант звернення до фольклору та етнографії демонструє I. Котляревський. Безумовно, в цілому його «Енеїда» має літературне походження, будучи ланкою в довгому ланцюжку інтерпретацій. Починати можна з Гомера, який увічнив тему Троянської війни, i, що важливіше - створив продуктивну схему оповіді. На цю модель орієнтувався Вергілій, який, на думку Г. Блума, став для європейської культури важливішим, ніж сам Гомер [Блум 2007: 600], в тому числі завдяки тому, що його герої ближче до новоєвропейської людини, ніж титанічні постаті «Іліади» та «Одиссеї». Його «Енеїда» - особливо в латиномовних країнах - мала статус канону. Але ж будь-яка святиня викликає у деяких людей бажання «знизити» $\dddot{1}$ - або злісно, в вигляді десакралізації, або ж у вигляді доброзичливого жарту. Одним з перших був П. Скаррон, за ним - Блюмауер чиї твори вплинули на М. Осипова, який в 1791 надрукував твір «Вергилиева Енеида, вывороченная наизнанку» - до речі, з цим текстом І. Дмитрієв згодом порівняв пушкінську поему «Руслан та Людмила», що $є$ цінним свідченням сприйняття ії комічних підтекстів сучасниками.

Котляревський запозичив у Осипова розмір вірша, деякі прийоми комедійного, а інколи й цілі уривки. Але при цьому, навіть дуже схожі пасажі звучать у нього помітно виразніше, красивіше та глибше. Порівняймо перший рядок у Осипова: «Эней был удалой детина // И самый хватский молодец» за загальновідомим «Еней був парубок моторний...».

На відміну від усіх аналогічних творів, «Енеїда» Котляревського стала не курйозом, а масштабним культурним явищем, яке було визнано відразу і зберегло свою актуальність дотепер. Котляревський «оформив» сучасну українську мову, створив енциклопедію побуту, описав національний характер. Одним з свідчень «прогностичної» здатності «Енеїди» є ілюстрації А. Базилевича, які осмислюють вже не два часових рівні (античність та козацтво), а три - додається досвід ХХ ст., зокрема, Другої Світової Війни.

$€$ в «Енеїді» і особлива загадка - що саме було відомо автору про Трою? Адже існують барокові українські та польські тексти, які порівнюють, а подекуди і ототожнюють Київ з Троєю. Крім того, саме від троянців виводили свою державність не лише римляни, але й британці (від Брута). Яка історична правда стоїть за цими легендами? В будь-якому разі, подібні історичні, чи хоча б псевдоісторичні перекази $є$ складовою частиною того спільного підгрунтя, яке єднає такі відмінні європейські країни як Туреччина, Італія, Британія та Україна.

При всій цій величезній смисловій щільності і наявності цілком серйозного підтексту, Котляревський використовує найрізноманітніші техніки комічного. Для тогочасної освіченої людини текст в цілому мав буги значно смішнішім, оскільки саме на тлі піднесеної класичної культури, 
яка сприймалася як нормативна, особливо виразно «грали» анахронізми, загальне заземлення образів та мотивів героїв, активізація рівню «тілесного низу» (М. Бахтін) тощо

Підхід до іроїкомічного жанру у О. Пушкіна відмінний. Взагалі, російський поет демонструє різні підходи до фольклору. Так, його казки ближче до обробки народних текстів (хоча не завжди російських, зокрема, «Казка про рибака та рибку» може мати німецькі джерела, «Балда» - має скандинавські паралелі). А от у «Руслана та Людмили» генеза значно складніша.

Як відомо, поема була започаткована ще в ліцеї, дуже молодим автором, який не ставив перед собою особливих надзадач (як, до речі і П. Єршов). Загальний тон $є$ легковажним, що особливо помітно у авторських відступах, відчувається вплив вольтерівської іронії, мають місце елементи пародії на поему В. Жуковського «Дванадцять сплячих дів». Поема є розважальною, без послідовного проведення якоїсь «великої» ідеї, або ж розробленого історичного або національного колориту. Проте написана вона настільки легко і цікаво, що стала миттєвою класикою і не втрачає популярності досі.

Генетично поема Пушкіна зв'язана з західноєвропейським роменсом («рицарським романом») - зокрема, автор орієнтувався на «Несамовитого Роланда» Аріосто. Ще одним джерелом була російська літературна казка як авторська, так і анонімна. Зокрема, ім'я заголовного героя виведено від імені Єруслана Лазаревича, героя книжної повести, який, в свою чергу, походить від Рустама 3 «Шахнаме». До речі, в останні роки відбулося повернення Сруслана в сферу активного читання - російський дитячий автор А. Усачов переповів його історію, та історію ще одного колись популярного героя - Бови-королевича - сучасною мовою; оформлення книжок стилізоване під лубок.

Вважається, що безпосереднім стимулом для Пушкіна був вихід в 1818 р. перших томів «Історії держави російської» М. Карамзіна, звідки, зокрема, взяті імена суперників Руслана. Отже, незважаючи на всі запозичення та літературні ігри автора, помітно його бажання звернутися не просто до фентезіного псевдоісторичного антуражу, а й певним чином торкнутися теми фундаменту російської державності - яка в ті часи (як і зараз) виводилася з Київської Русі.

В поемі ліризм та героїка вдало сполучаються 3 комізмом. Багато гротеску в образ Фарлафа та в першій появі Голови. Але й про свою чарівну героїню Пушкін може сказати «По солнцу бегая с утра... „», або ж з гумором показати типово дівочу (на його думку) непослідовність: Людмила вирішує уморити себе голодом і заявляє: «Умру среди твоих садов!» // Подумала и стала кушать. Грайливий гумор часто виникає в авторських відступах на зразок:

Но, верьте мне, блажен и тот,

Кто от Дельфиры убегает

И даже с нею незнаком...

Статус позачасової класики, яку поступово набула поема Пушкіна, вимагав створення перекладів мовами народів СРСР. В Україні до неї зверталися талановиті автори, зокрема, М. Рильский, але популярності їхні твори не набули. Основною проблемою було те, що майже буквальна близькість до оригінального тексту досягалася за рахунок легкості та природності. Наприклад, у М. Терещенка:

Край лукомор'я дуб зелений,

І золотий ланцюг на нім:

Щодня, щоночі кіт учений

На ланцюгу кружляє тім;

Іде праворуч - спів заводить,

Ліворуч - казку повіда...

Дива там: лісовик там бродить,

В гіллі русалка спить бліда.

Врешті решт, оскільки більшість українців знали російську мовута вчили Пушкіна в школі, простіше було прочитати твір в оригіналі. Художня неадекватність перекладів сприймалася як погана, але неминуча. Поштовхом для нової спроби міжкультурного діалогу стала якраз фраза журналістки, яка стверджувала принципову неперекладність пушкінської поезії, наводячи як доказ фразу «У лукоморья дуб зеленый...» [Блум 2007: 5], Це твердження спонукало взятися за переклад доволі несподівану людину - останнього голову Ради Міністрів УРСР та першого прем’єр-міністра незалежної України Вітольда Фокіна. Зокрема, ця перша «неперекладна» фраза виглядає у нього так:

Край лукомор'я дуб зелений,

Ланцюг на ньому золотий,

Щодень круг дуба Кіт учений

Ступає, наче вартовий.

Праворуч йде - пісні співає,

Ліворуч - казку муркотить.

Там в хащах лісовик блукає

І мавка на гіллі сидить.

Принципова відмінність від попередніх версій полягає в тому, що це не дослівний переклад, а переспів. Як відомо, від самого виникнення літератури і до першої половини XIX ст. поняття авторства було не таким чітким як зараз, і перекладач часто виступав в ролі інтерпретатора-співавтора. В наш 
час такий підхід зустрічається нечасто, зокрема, через питання копірайтів, однак не зникає повністю та вступає у взаємодію 3 іншими формами інтертекстуальності.

В. Фокін спробував поєднати дві відмінні національні традиції, кожна зі своєю моделлю гумору. Для українізації самого життєвого світу поеми Пушкіна породжуючою моделлю закономірним чином стала творчість I. Котляревського.

Можна спробувати виділити основні вектори змін, які відбулися в переказі В. Фокіна в порівнянні з першоджерелом:

1. «Повернення» історії Руслана та Людмили до Києва, але вже не як «російського», а як давньоукраїнського міста. Київський князь, кияни як такі (у сцені нападу печенігів) виглядають виразніше та активніше, ніж у Пушкіна. Як це властиво українській мові, автор розрізняє слова «російський» (яке в тексті не фігурує) та «руський». Тому закономірно, що «русским духом пахнет» передається як «Химерний світ, прадавня Русь! // Її збагнуги не берусь...» [Фокін 2015:9]. Кліше з російських казок в будь-якому разі важко передати дослівно. А ідейний акцент ставиться чітко.

2. Насичення староукраїнською побутовою конкретикою. Саме тут найширше використовується спадщина Котляревського. Зокрема, дуже близьким $є$ як використання архаїчної за походженням поетики перерахувань по відношенню до такого повсякденного рівня як каталог страв національної кухні: «Все парувало і шкварчало: // Зубці, кров’янка, добре сало, // Куліш, потапці та хляки, // Драглі, ковбаси, пиріжки...» [Фокін 2015: 11],--і так далі на цілу сторінку. Хоча, враховуючи, по-перше, що описана кухня князівська, до того ж обрядова, весільна, а по-друге, роль гастрономічного мистецтва в людській культурі, в тому числі в етнонаціональному коді,- такий кулінарний каталог набуває власного елементу піднесеності, в чомусь спорідненої з піднесеністю голландських натюрмортів. За рахунок використання автором історизмів та екзотизмів, відбувається суттєве збагачення лексики твору, розуміння якої вимагає спеціального глосарія, який додається в кінці книги.

3. Посилення ліричного моменту. В 1830 році, через десять років після виходу першої редакції, О. Пушкін сам писав, що його не влаштовує у власній поемі відсутність справжнього почуття - вона «холодна». Зазвичай захоплений читач не помічає цього, домислюючи і обставини знайомства героїв, і їхні почуття. А ось при роботі над перекладом це стало помітно. Сам В. Фокін пише, що: «читача умовляють повірити, що свої подвиги Руслан вершить заради Людмили, а мотивація його вчинків не доведена, бо про справжні почуття, про те, що герої давно люблять один одного - нема ні рядка» [Фокін 2015: 6]. Тому перекладачспівавтор додав деякі сюжетні подробиці та психологічні нюанси.

Як подібні трансформації впливають на характер комічного елементу поеми? Котляревський використав по відношенню до свого першоджерела стратегію зниження, що виглядає ефектно в порівнянні 3 абсолютно серйозною «Енеїдою» Вергілія. Але застосування зниження до «Руслана i Людміли» не продуктивно, тому що поема і так не $є$ абсолютно серйозною, а створення пародії на гумор - в більшості випадків справа безперспективна. Перекладати дослівно всі жарти людини початку XIX ст.? Звісно, в деяких випадках гумор Пушкіна є смішним і через двісті років. Але В. Фокін вирішив знайти скоріше функціональні еквіваленти за рахунок власне українських реалій («гарбузом нагородила»). За стилістикою евфемізми явищ фізіологічного характеру («Такі пани не ходять пішки // Навіть туди, куди б і слід»), знаходиться приблизно між Пушкіним та Котляревським. Так само, як Пушкін та Котляревський, Фокін використовує анахронізми, тільки вже пов’язані з нашим власним часом: («горб, немов рюкзак»). Використання подібних виразів при оповіді про давній Київ створює ефект відсторонення та легкої іронії оповідача.

Сам цей образ оповідача у Фокіна $є$ набагато менш чіткім, ніж у Пушкіна. Зате несподівано виникає другий оповідач - той самий Кіт вчений, який диктує цю історію автору. ІІхнім коротким діалогом звершується кожний розділ. Як відомо, у Пушкіна пролог про Лукомор'є з'явився лише в другій редакції, і може сприйматися і навіть друкуватися в якості окремого твору. У Фокіна Лукомор'є та Кіт - створюють не лише рамку, але й обов'язковий конструктивний елемент цілого. Це найкраще помітно в фіналі. У Пушкіна поема закінчується елегійним епілогом (теж написаним пізніше), який завершується меланхолійно: «И скрылась от меня навек богиня тихих песнопений...».

У Фокіна фінал оформлений Післямовою, яку навожу повністю:

Я поспіхом кінчав сторінку,

Кіт задоволено мовчав.

Порожню чарку облизав,

3’їв хліба житнього шкуринку.

І вже як я поставив крапку,

Простяг мені поштиво лапку,

Навколо дуба почвалав,

Та озирнувся і сказав:

«Мерсі, горілка підходяща,

Та все-таки сметана краща!» [Фокін 2015: 142].

Гадаю, і характер комічного, і безсумнівно українська ментальність Кота 
тут цілком очевидна.

«Повернення» київської поеми Пушкіна до України відбулося не лише в вигляді переказу В. Фокіна. Слід згадати також анімаційнустрічку «Викрадена принцеса: Руслан і Людмила» (режисер О. Маламуж, 2018 р.). Характеристика цього твору не входить в тему статті; скоріше привертають увагу прояви того специфічного притягування-відштовхування до російської культури, яке має місце в Україні в останні роки. Повністю відмовитися від традиційного впливу російської культури важко, але ж ії сприйняття є сильно трансформованим через загальновідомі сучасні політичні та ідеологічні реалії. Тому автори стрічки звертаються до загальновідомого першоджерела, але не посилаються на Пушкіна і роблять героїв та сюжет принципово відмінними. Як би там не було, «Викрадена принцеса» стала рекордсменом вітчизняного прокату серед фільмів українського виробництва та вийшла на міжнародний рівень. На черзі - Мавка (не зовсім та, що у Лесі Українки) та Роксолана (теж, ймовірно, не зовсім така, якою їі знала історія).

Враховуючи славні традиції української анімації та світовий рівень наших художників, будемо сподіватися, що ці проекти стануть успішними.

Висновки. Жанр роменсу (різні його варіанти позначаються то як «рицарський роман», то як «казка для дорослих» тощо) в наш час користується певною популярністю. Про що свідчить як регулярне перевидання, переклад, ілюстрація, екранізація класичних творів, так і виникнення нових зразків жанру. Переказ-переспів «Руслана і Людмили» В. Фокіна знаходиться на межі між перекладом як таким та цілком оригінальним художнім текстом. В цілому його можна оцінювати як вдалий - і як засіб міжкультурного діалогу, і як доказ адекватності української мови для передачі тексту найвищого рівня художності. Зокрема, при передачі різних форм комічного і іншомовних, іншокультурних, історично віддалених текстах, які слід популяризувати серед широкого читацького загалу, саме співавторське пере-створення мистецького опусу є адекватнішим, ніж спроба абсолютно дослівного перекладу.

\section{Список використаних джерел}

Блум, Г. (2007) Західний канон: книги на тлі епох / пер. з англ. під заг. ред. Р. Семківа. Київ, Факт, 720 с.

Фокін, В.П. (2015) Руслан і Людмила: Переказ поеми О. С. Пушкіна, Харків, Фоліо, 159 с.

Елена Колесник

\section{КОМИЧЕСКОЕ В ПЕРЕВОДЕ «РУСЛАНАИЛЮДМИЛЫ} В. ФОКИНА

В статье делается обзор нескольких поэм XIX века, в которых авторы обрашаются к литературным и фольклорно-этнографическим источникам, перерабатывая их в ироническом духе. При примере пересказа пушкинской поэмы «Руслан и Людмила»В. Фокина демонстрируется сходство и различие подхода к той же теме в оригинале и перепеве.

Ключевые слова: «Руслан и Людмила», «Энеида», комическое, перевод.

\section{COMICALINV.FOKIN'S TRANSLATION OF"RUSLANAND \\ LUDMILLA"}

In the late XVIII - early XIX ct. in the Russian empire appeared several poems that used the literary and folklore sources in the humorous way. Some of them become classics, and helped to define the development of the later literary tradition. In Ukrainian literature we see I. Kotlyarevskiy's "The Aeneid", that is much more than another travesty of Virgil's poem. This text became an encyclopedia of Ukrainian culture, and even its "lower registers" paradoxally creates the feeling of the sublime. Russian classical text was "Ruslan an Ludmilla" by A. Pushkin that is much more lyrical (as opposite to epic) and intimate in nature, and where the comical element is mostly seen in the narrator's gentle humor. The existing Ukrainian translations of the poem are talented, but lacking in some special feeling of naturalness. To achieve the effect of the spontaneity, V. Fokin decided to create not a word-by-word translation, but a retelling, using the authentic material of Ukrainian language and tradition. In this, the heritage of Kotlyarevskiy, especially, his specific comical touch, was of much help. Generally, the new Ukrainian text of "Ruslan and Ludmilla" is a successful retelling of the classical story for the new audience, and a proof that Ukrainian language is much richer and subtler than it is sometimes thought.

Keywords: "Ruslan an Ludmilla", "The Aeneid", the comical, translation.

\section{References}

Blum, G. (2007) Zaxidnyj kanon: knygy na tli epokh [Western canon: books on the background of epochs], per. $z$ angl. pid zag. red. R. Semkiva. Kyiv, Fakt, 720 p.

Fokin, V. P. (2015) Ruslan i Lyudmyla: Perekaz poemy O. S. Pushkina [Ruslan and Lyudmila: Translation of a poem by A. S. Pushkin], Kharkiv, Folio, $159 \mathrm{p}$.

Стаття надійшла до редакиї̈ 27.04.2020

Стаття прийнята 27.05.2020 